\title{
APPROACH OF SELECTED BUSINESS ENTITIES TO GDPR IMPLEMENTATION
}

\author{
Marie Černá $^{1}$; Radek Sieber ${ }^{2}$ \\ University of West Bohemia, Faculty of Economics, Department of Finance and Accounting \\ Univerzitní 22, 30614 Plzeň, Czech Republic \\ e-mail: ${ }^{1}$ macerna@kfu.zcu.cz; ${ }^{2}$ sieber@ students.zcu.cz
}

\begin{abstract}
Personal data protection represents an issue which began to be dealt with in the context of religious conflicts and came to the fore after the Second World War when possible negative consequences of the misuse of personal data were made visible. Personal data protection is currently mentioned in relation with the implementation of General Data Protection Regulation (GDPR) by EU member countries. The objective of this article is to evaluate attitudes of further specified research sample consisting of entrepreneurial entities doing business in the Czech Republic to the changes set by the new legislative regulation of data protection. This article presents mainly the results of quantitative research based on data gathered through a questionnaire survey processing, identifies the weak areas of GDPR implementation process and proposes possible improvements leading to a more comfortable transition of business entities to the current legislative conditions in the area of personal data protection set by the European Parliament and the Council of the European Union.
\end{abstract}

\section{Keywords}

Business entities; GDPR; Personal data protection; Data protection; General regulation.

\section{Introduction}

The tendency to protect personal data arose in relation to religious conflicts that led to the persecution of people with different religious beliefs. The need for personal data protection conduced to greater caution and efforts to protect privacy. The need to protect personal data came to the fore after the Second World War that showed the negative consequences of personal data misuse, in this case in the form of genocide [1], [2].

The first written document dealing with privacy protection is said to be the French Declaration of the Rights of the Man and of the Citizen of 1789 [2]. The first tendencies to protect privacy are, according to Weibull [3], also visible in regulation of access to public records in Sweden in 1766.

Table 1 summarizes written documents which include references to privacy protection (personal data protection). 
Tab. 1: Written documents dealing with privacy protection

\begin{tabular}{|l|l|}
\hline Document creation & Title of the document \\
\hline 1789 & Rights of the Man and of the Citizen \\
\hline 10.12 .1948 & Universal Declaration of Human Rights \\
\hline 4.11.1950 & European Convention on Human Rights \\
\hline 16.12.1966 & International Covenant on Civil and Political Rights \\
\hline 24.10 .1981 & Council of Europe Convention No. 108 on data protection \\
\hline 25. 5.2018 & $\begin{array}{l}\text { Directive 95/46/EC of the European Parliament and of the Council } \\
\text { Regulation (EU) 2016/679 of the European Parliament } \\
\text { persons with regard to the processing of personal data and on the free } \\
\text { movement of such data, and repealing Directive 95/46/EC (General } \\
\text { Data Protection Regulation) }\end{array}$ \\
\hline
\end{tabular}

Source: Own with respect to [2], [3], [4], [5], [6] and [7]

The development of human rights protection in the Czech Republic was different from the development of human rights protection in other states in Western Europe. It was caused by the differences in governing regimes. Personal data protection started to be solved in the Czech Republic since the 90s of the 20th century. The first adopted legislative regulation was the Act No. 256/1992 Coll. on personal data protection in information systems. Next adopted legislative regulation was the Act No. 101/2000 Coll. on personal data protection that was prepared and implemented with respect to the application of the Czech Republic for European Union membership. This regulation included the principles of Council of Europe Convention No. 108 on data protection and Directive 95/46/EC of the European Parliament and of the Council. As visible from the Table 1 above, the Regulation (EU) 2016/679 of the European Parliament and of the Council of 27 April 2016 on the protection of natural persons with regard to the processing of personal data and on the free movement of such data, and repealing Directive 95/46/EC (General Data Protection Regulation) are currently in force. The last mentioned regulation had to be implemented by all member states of the European Union till 25. 5. 2018. Despite this regulation, some businesses in the Czech Republic were not interested in the issue. The reasons and impacts of their behavior are described in more detail in the following chapters.

\section{$1 \quad$ Main Objectives and Principles of GDPR}

GDPR can be defined as the legislatively given guidance for personal data processing in all countries belonging to the EU. GDPR is obligatory, but selected areas may be further regulated by individual states, for example the level of sanctions resulting from the infringement of the Regulation [8]. Four main objectives of GDPR are defined by Navrátil [1] as:

1. The adaptation of legal regulation and personal data protection to current conditions.

2. Standardization of data protection in all European Union countries and other states participating on GDPR.

3. Strengthening the rights of privacy of all subjects of personal data protection and achieve the unified interpretation of GDPR by supervisory authorities of European Union countries.

4. Strengthening the credibility of the European Union and its Member States (and other countries covered by the GDPR) for other countries interested in trade relations with the European Union and related transfer of personal data between the countries. 
GDPR is said to be based on six principles [9]:

1. Transparency of the personal data processing.

2. Limitations of personal data processing only for legitimate purposes.

3. Limitation of personal data collection and storage only for intended purposes.

4. Possibility to make changes in personal data by their subject or to remove them completely.

5. Data storage limits only for the time necessary relating to the given purpose.

6. Ensuring adequate privacy of personal data by effective procedures.

GDPR was set on 24 May 2016, but it came into force in 2018 and the possibility of its effective enforcement was postponed to May 25, 2018 [10]. Preparation of GDPR implementation is usually divided into several parts visible in Figure 1.

Source: Own

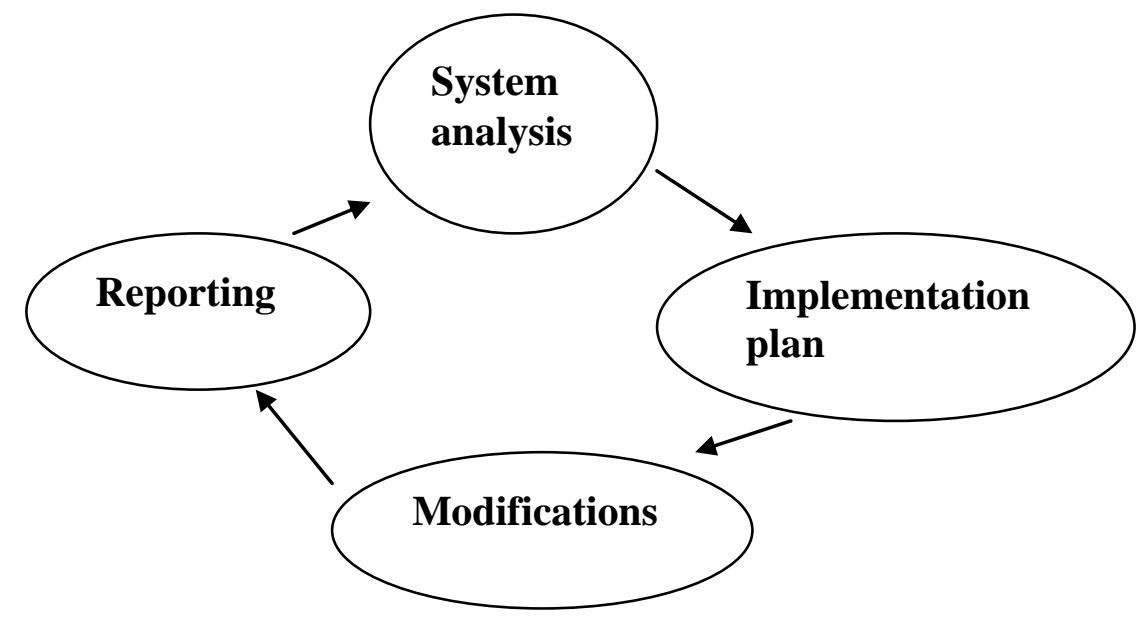

Fig. 1: GDPR implementation preparation phases

The system analysis tries to answer six questions:

1. Why? - The purpose of personal data processing.

2. About whom? - Identification of the subject of data.

3. What? - Personal data type, source and legislative purpose for their gathering.

4. When? - Date and frequency of data gathering, archiving time.

5. How? - Method of data processing.

6. Who? - Identification of people processing and accessing the data [11].

The Ministry of Education, Youth and Sports developed the methodics for GDPR implementation which can be used with small changes also for the business sector. This methodics is based on set activities that have to be ensured in relation to GDPR implementation and is available on the web pages of the Ministry of Education, Youth and Sports.

The following parts of this article are focused on analyzing attitudes of selected business entities in the Czech Republic to GDPR and on identification of weak areas in the process of GDPR implementation. 


\section{$2 \quad$ Research Objectives}

The main objective of this article and the conducted research was to analyze, asses and summarize expected effects of GDPR implementation from the point of view of business entities doing business in the Czech Republic and having something in common with the new Regulation (EU) 2016/679 of the European Parliament and of the Council of 27 April 2016 on the protection of natural persons with regard to the processing of personal data and on the free movement of such data, and repealing Directive 95/46/EC (General Data Protection Regulation) [7] and to propose possible improvements leading to more comfortable transition of business entities to the current legislative conditions in personal data protection set by the European Parliament and the Council of the European Union. The main objective was subdivided into several individual sub-objectives:

1. To identify and describe the historical milestones of personal data protection in Europe and in the Czech Republic with respect to international legislative framework in this area.

2. To conduct quantitative research of readiness of selected business entities in the Czech Republic for GDPR implementation.

3. To propose possible improvements of weak areas identified during the analysis of the current situation in personal data protection with respect to the necessity of GDPR implementation.

\section{$3 \quad$ Research}

\subsection{Research Methods}

Based on the identification and description of the main historical milestones related to personal data protection, the fundamental reasons leading to the need of change in legislative framework for this area were explained. Detailed document analysis (literary research), participating observations and non-standardized conversation were used as the methods leading to questionnaire creation. These activities were followed by the executive phase represented by analyzing the data and their evaluation. Based on the analysis, six hypotheses were evaluated:

1. Half of all respondents have not started preparation for GDPR implementation.

2. At least one third of respondents who started the process of GDPR implementation preparation used the help of a partner.

3. There is a relationship between legal subjectivity and starting the process of GDPR implementation preparation.

4. The main problem for business entities will be lack of availability of information relating to this issue.

5. There is a relationship between legal subjectivity and selection of partner for GDPR implementation preparation.

6. Entities already preparing for GDPR expected higher costs than those entities who are just preparing for starting the preparation for GDPR implementation.

\subsection{Research Background}

After creation of a questionnaire consisting of 16 questions, the own data gathering started. The research was conducted from January 2018 to March 2018 with the intention to prepare 
the submitted article and also the diploma thesis dealing with the GDPR issue. This article therefore uses the same database as the diploma thesis listed in the literature [12].

The used questionnaire was in electronic form and was created on the platform www.vyplnto.cz. The request for completion was sent to selected business entities.

The gathered data were evaluated during April 2018 and the results were summarized in the final report at the end of April 2018. Data evaluation was performed using methods of statistical analysis; the subject of the research was the frequency of the responses and the relationships between them.

The questions used in the questionnaire were modified to meet primarily the descriptive function. They were divided to three parts. The first part of the questionnaire was focused on general information about analyzed business entities, the second part divided business entities to those who were already preparing for GDPR implementation and others, and the last part dealt with the process of GDPR implementation phases and expected costs related to this process. Individual questions are summarized in Table 2.

Tab. 2: Questions used in the questionnaire survey

\begin{tabular}{|r|l|}
\hline $\begin{array}{l}\text { Question } \\
\text { No. }\end{array}$ & Specification \\
\hline 1 & Legal form of business. \\
\hline 2 & Branch of business. \\
\hline 3 & Size of the enterprise. \\
\hline 4 & Do you prepare your company on GDPR implementation? \\
\hline 5 & At what stage of preparation for GDPR implementation is your company? \\
\hline 6 & $\begin{array}{l}\text { Was your GDPR implementation preparation done in cooperation with any } \\
\text { partner? }\end{array}$ \\
\hline 7 & What were your estimated costs associated with GDPR implementation? \\
\hline 8 & $\begin{array}{l}\text { What time requirements related to GDPR implementation preparation do you } \\
\text { expect? }\end{array}$ \\
\hline 9 & What are your current total costs associated with GDPR implementation? \\
\hline 10 & How long in total does/did your preparation for GDPR implementation take? \\
\hline 11 & $\begin{array}{l}\text { What was the most significant expected problem related to GDPR } \\
\text { implementation? }\end{array}$ \\
\hline 12 & What was the real most significant problem during GDPR implementation? \\
\hline 13 & Are you planning any preparation for GDPR implementation? \\
\hline 14 & Which costs associated with GDPR implementation do you expect? \\
\hline 15 & What time requirements related to GDPR implementation do you expect? \\
\hline 16 & $\begin{array}{l}\text { What is currently your most significant expected problem related to GDPR } \\
\text { implementation? }\end{array}$ \\
\hline
\end{tabular}

\subsection{Research Sample}

Research sample used for the quantitative research consisted of business entities doing their business in the Czech Republic regardless of their location. This specification takes into account the fact that GDPR has an area scope of the entire Czech Republic. Some respondents were also asked to participate in expert interviews conducted with the aim to analyze the information provided in the questionnaire survey in detail. The final amount of respondents included in the questionnaire survey was 75 business entities located in the Czech Republic. 
The respondents were divided to three different legal forms of business. $38(50.67 \%)$ respondents belonged to self-employed persons, 34 (45\%) respondents belonged to limited liability companies (Inc.) and 3 respondents (4\%) represented joint stock companies. The most often selected branch of respondents' business was photography, video and graphics. Other respondents came from the areas like manufacturing, mechanical engineering, software and IT services, crafts, construction or hospitality services.

The respondents most often belonged to the group of micro enterprises ( 54 respondents), 12 respondents represented small enterprises and 6 respondents came from the group of large enterprises. The rest, 3 respondents, were from medium-sized enterprises.

\section{$4 \quad$ Research Results}

This part of the article deals with the evaluation of responses to all questions asked. Individual questions were analyzed in a comprehensive way and selected questions for various sizes of enterprises and various legal subjectivity individually. The authors also used the Fisher's exact test which enabled them to evaluate responses to questions 4 and 6 . Linear regression was used to determine the type of relationship between the gathered data.

The gathered data outlined the fact that only $49 \%$ of the respondents deal with the preparation for GDPR implementation. Preparation for GDPR implementation was declared by 37 respondents. This result supports the first set hypothesis. Responses to question number 4 are summarized by Table 3 and Table 4 .

Tab.3: Relation between the size of the enterprise and preparation for GDPR implementation

\begin{tabular}{|l|r|r|r|r|}
\hline & $\begin{array}{l}\text { Micro } \\
\text { enterprise }\end{array}$ & $\begin{array}{l}\text { Small } \\
\text { enterprise }\end{array}$ & $\begin{array}{l}\text { Medium-sized } \\
\text { enterprise }\end{array}$ & $\begin{array}{l}\text { Large } \\
\text { enterprise }\end{array}$ \\
\hline $\begin{array}{l}\text { Preparation } \\
\text { started }\end{array}$ & $37 \%$ & $75 \%$ & $67 \%$ & $100 \%$ \\
\hline $\begin{array}{l}\text { No preparation } \\
\text { yet }\end{array}$ & $63 \%$ & $25 \%$ & $33 \%$ & $0 \%$ \\
\hline Total & $100 \%$ & $100 \%$ & $100 \%$ & $100 \%$ \\
\hline
\end{tabular}

Source: Own

Tab. 4: Relation of legal subjectivity of the enterprise and preparation for GDPR implementation

\begin{tabular}{|l|l|l|l|}
\hline & \multicolumn{2}{|l|}{ Legal subjectivity } \\
\hline Preparation & $\begin{array}{l}\text { Self-employed } \\
\text { person }\end{array}$ & $\begin{array}{l}\text { Limited liability } \\
\text { company }\end{array}$ & $\begin{array}{l}\text { Joint stock } \\
\text { company }\end{array}$ \\
\hline $\begin{array}{l}\text { Yes (number of } \\
\text { subjects) }\end{array}$ & 10 & 24 & 3 \\
\hline $\begin{array}{l}\text { No (number of } \\
\text { subjects) }\end{array}$ & 28 & 10 & 0 \\
\hline
\end{tabular}

Source: Own

Data summarized by Table 4 were used as the basis for Fisher's exact test [13]. Null hypothesis was defined as "Preparation for GDPR implementation is independent of legal subjectivity." $P$-value was calculated as 0.0001 ; therefore the null-hypothesis was rejected. This result confirms set hypothesis which states that there is a relationship between legal subjectivity and starting the process of GDPR implementation preparation. 
The fifth question already concerns only the respondents who started their preparation for GDPR implementation. Within the question number five was studied the relationship between company size and phase of preparation for GDPR implementation. Results show that the greatest amount of companies is currently in the phase of system analysis. Results are summarized in Table 5.

Tab. 5: Relation of company size and phase of preparation for GDPR implementation

\begin{tabular}{|l|c|c|r|r|}
\hline & \multicolumn{2}{|l|}{$\begin{array}{l}\text { Micro } \\
\text { enterprise }\end{array}$} & $\begin{array}{l}\text { Small } \\
\text { enterprise }\end{array}$ & \multicolumn{2}{l|}{$\begin{array}{l}\text { Medium-sized } \\
\text { enterprise }\end{array}$} & \multicolumn{1}{l|}{$\begin{array}{l}\text { Large } \\
\text { enterprise }\end{array}$} \\
\hline System analysis & $55 \%$ & $44.5 \%$ & $100 \%$ & $50.0 \%$ \\
\hline $\begin{array}{l}\text { Implementation } \\
\text { plan }\end{array}$ & $20 \%$ & $11.1 \%$ & $0 \%$ & $16.6 \%$ \\
\hline Modifications & $10 \%$ & $33.3 \%$ & $0 \%$ & $16.7 \%$ \\
\hline $\begin{array}{l}\text { Company is } \\
\text { prepared }\end{array}$ & $15 \%$ & $11.1 \%$ & $100 \%$ & $100.0 \%$ \\
\hline Total & $100 \%$ & $100.0 \%$ & & \\
\hline
\end{tabular}

Source: Own

Answers to question number six confirmed the second research assumption, because $42 \%$ of respondents that were preparing for GDPR implementation answered positively. It means that at least one third of the respondents who started the process of GDPR implementation preparation used the help of a partner. Table 6 brings more detailed information about this issue and Table 7 was prepared as the basis for Fisher's exact test. Null hypothesis was defined as "Selecting preparation for GDPR implementation with partners' help is independent of legal subjectivity." P-value was calculated as 0.5144 ; therefore the nullhypothesis could not be rejected. This result did not confirm set hypothesis which states that there is a relationship between legal subjectivity and selection of partner for GDPR implementation preparation.

Tab. 6: Relation between size of the entity and selection of partner for GDPR implementation preparation

\begin{tabular}{|l|c|c|c|c|}
\hline & $\begin{array}{l}\text { Micro } \\
\text { enterprise }\end{array}$ & $\begin{array}{l}\text { Small } \\
\text { enterprise }\end{array}$ & $\begin{array}{l}\text { Medium-sized } \\
\text { enterprise }\end{array}$ & $\begin{array}{l}\text { Large } \\
\text { enterprise }\end{array}$ \\
\hline $\begin{array}{l}\text { We use the } \\
\text { partners' help }\end{array}$ & $35 \%$ & $33 \%$ & $50 \%$ & $83 \%$ \\
\hline $\begin{array}{l}\text { We solve GDPR } \\
\text { ourselves }\end{array}$ & $65 \%$ & $67 \%$ & $50 \%$ & $17 \%$ \\
\hline Total & $100 \%$ & $100 \%$ & $100 \%$ & $100 \%$ \\
\hline
\end{tabular}

Source: Own

Tab.7: Relation of legal subjectivity of the enterprise and selection of partner for preparation for GDPR implementation

\begin{tabular}{|l|l|c|c|}
\hline & \multicolumn{2}{|l|}{ Legal subjectivity } \\
\hline Partner & $\begin{array}{l}\text { Self-employed } \\
\text { person }\end{array}$ & $\begin{array}{l}\text { Limited liability } \\
\text { company }\end{array}$ & $\begin{array}{l}\text { Joint stock } \\
\text { company }\end{array}$ \\
\hline $\begin{array}{l}\text { Yes (number of } \\
\text { subjects) }\end{array}$ & 3 & 11 & 2 \\
\hline $\begin{array}{l}\text { No (number of } \\
\text { subjects) }\end{array}$ & 7 & 13 & 1 \\
\hline
\end{tabular}

Source: Own 
Question number seven deals with the estimated costs related to GDPR implementation by business entity. The results showed that $76 \%$ of respondents expected the cost ranging from 1 to $50,000 \mathrm{CZK}, 19 \%$ of respondents selected the option 50,000 to $150,000 \mathrm{CZK}$ and the possibility 150,000 to $400,000 \mathrm{CZK}$ was selected by $5 \%$ of respondents. The most often estimated time requirements for GDPR implementation preparation were in the range of $0-1$ month ( $46 \%$ of respondents), $27 \%$ of respondents selected the option $2-4$ months, $22 \%$ of respondents thought it will be $1-2$ months and finally $5 \%$ of respondents selected the option 4 months and more. The greatest amount of analyzed business entities (84\% of respondents) stated that their costs related to GDPR implementation preparation were till the day of questionnaire survey in the range of $1-50,000 \mathrm{CZK}$, only $16 \%$ of respondents selected range $50,000-150,000 \mathrm{CZK}$. Only $13 \%$ of respondents that started the preparation for GDPR implementation were in the final phase of preparation. This may have led to distortion of conclusions. Business entities were not able to quantify the costs, because they were still expecting their increase.

Based on the research results, only 5 respondents (from the total amount of 75 respondents) completed the preparation for GDPR implementation. Preparation took maximally 2 months. Because of such a low amount of respondents with finalized preparation for GDPR implementation the answers to question number 10 had no adequate informative value.

Questions 11, 12 and 16 were open questions. The authors had expected different experience of respondents in the area of GDPR implementation preparation. The research identified lack of information to GDPR issue and particular solutions that would be sufficient for potential control as the most often expected problematic factors. To other mentioned problems belonged concerns about data security, publishing photos, internal standards and processes adjustments, IT solutions, administrative burden or consent to personal data processing. These expectations were confirmed by the responses of the respondents who were already preparing the GDPR implementation to question number 12. The answers highlighted the lack of information to GDPR issue, or the existence of various interpretations of the issue.

Question number 13 surveyed the respondents' plans in the area of preparation for GDPR in the near future. $42 \%$ of respondents selected the answer "We want to start the preparation for GDPR implementation when it comes into force". $32 \%$ of respondents selected the answer "No, we will not start the preparation for GDPR". 26\% of respondents selected the answer "We want to start the preparation for GDPR implementation before it comes into force". Preparation for GDPR implementation is most often omitted by self-employed persons.

Questions 14, 15 and 16 were prepared for business entities that had had no experience with GDPR implementation preparation before the date of the survey conduction. These respondents most often ( $76 \%$ of such respondents) expected that the time requirements of GDPR implementation preparation would be in the range $0-1$ month. The most significant problems defined by these business entities were described as lack of information about GDPR issue and excessive time demands of GDPR implementation preparation. Responses to question number 14 are summarized in Table 8.

Tab. 8: Estimates of regression coefficients and standard deviation of linear regression analysis (in $C Z K$ )

\begin{tabular}{|l|c|c|c|c|}
\hline Partner & $\begin{array}{l}\text { Readiness for } \\
\text { GDPR }\end{array}$ & $\begin{array}{l}\text { Joint stock } \\
\text { company }\end{array}$ & $\begin{array}{l}\text { Self-employed } \\
\text { person }\end{array}$ & Absolute term \\
\hline Regression coefficient & 10,268 & 117,078 & $-2,768$ & 30,987 \\
\hline Standard deviation & 8,177 & 18,859 & 8,177 & 7,854 \\
\hline
\end{tabular}

Source: Own 
Expected costs associated with the GDPR implementation by business entities were analyzed using the linear regression including information about the legal forms of the business entities and information about the phase of business entity preparation for GDPR implementation. Estimated cost intervals have been adjusted to mean values for these intervals. This may cause variations in calculation. Estimates of regression coefficients and standard deviation are shown in Table 8. Absolute term indicates the average estimated cost of the company, which corresponds to the basic categories. Calculation was used by a company with legal subjectivity - limited liability company (Inc.), which was not prepared for GDPR implementation. The remaining values in the first line of the Table 8 represent differences in the average estimated costs of other legal entities compared to the absolute term. The first column of the Table 8 indicates the difference between the entities that have started the preparation for GDPR implementation and those who have not started their preparation yet.

The entities under preparation for GDPR implementation estimate their costs about 10,000 CZK higher than the entities which have not started preparation for GDPR implementation. Due to insufficient amount of data, general conclusions cannot be made. The regression coefficient is not statistically significant.

The above mentioned results should not confirm the sixth expectation that entities already preparing for GDPR expected higher costs than those entities who are just preparing for starting the preparation for GDPR implementation. By contrast, the hypothesis number 4 that the main problem for business entities will be the lack of availability of information relating to this issue was verified by answers to questions number 11 and 16.

\subsection{Proposals based on research results}

Conducted research led to setting two proposals:

1. Creation and management of an internet portal, which would deal with the issue of GDPR. This portal should be under the auspices of the Office for Personal Data Protection and should inform about current problems related to this issue. It should be taken as guidance for GDPR implementation with available sample documents (consents to personal data processing or amendments to contracts).

2. Realization of regional seminars or workshops that would provide a comprehensive and clear picture of personal data protection. This proposal was defined in accordance with the finding that the preparation for GDPR implementation is most likely to be delayed by micro-enterprises mainly represented by self-employed persons.

The above mentioned proposals were set during the gathered data evaluation that was done before the Regulation (EU) 2016/679 of the European Parliament and of the Council of 27 April 2016 on the protection of natural persons with regard to the processing of personal data and on the free movement of such data, and repealing Directive 95/46/EC (General Data Protection Regulation) came into force. The current situation has changed, therefore the first proposal should be considered once more, using the results of further research (qualitative or quantitative) in the area of personal data protection regulation.

\section{Conclusion}

This article provides an insight to the personal data protection issue. Significant historical milestones identifiable in this area are introduced in the first sections of the article. These milestones are represented by issuing documents that govern the protection of privacy and personal data. Next sections of the article are devoted to the quantitative research conducted in the area of personal data protection regulation. Data analysis including the Fisher's exact 
test and linear regression analysis confirmed set hypothesis number 1, 2, 3 and 4. Hypothesis number 5 and 6 were not confirmed. Individual findings are mentioned in more detail in the section Research Results. Two proposals designed as solutions of problematic issues were explained in the section 4.1. Personal data protection and its regulation are the issues that need to be further examined. Further research results should enable to improve the designed proposals and to verify the results of the research conducted by the authors of this article.

\section{Acknowledgements}

This work was supported by the SGS-2017-004 "Finance and Sustainable Development from the Perspective of Theory and Practice Project".

\section{Literature}

[1] NAVRÁTIL, J.: GDPR pro praxi. Vydavatelství a nakladatelství Aleš Čeněk, Plzeň, 2018. ISBN 978-80-7380-689-7.

[2] ČSÚ: Československé sčitání lidu 1930. [online]. 2018. [accessed 2018-03-26]. Available from WWW: https://www.czso.cz/csu/sldb/ceskoslovenske_scitani_lidu_1930

[3] BRITANNICA.COM: Freedom of the Press Act of 1766. [online]. 2018. [accessed 2018-06-01]. Available from WWW: https://www.britannica.com/topic/Freedom-ofthe-Press-Act-of-1766

[4] UNITED NATIONS: Universal declaration of Human Rights. [online]. 2018. [accessed 2018-06-01]. Available from WWW: https://www.un.org/en/universal-declarationhuman-rights/

[5] OHCHR: International Covenant on Civil and Political Rights. [online]. 2018. [accessed 2018-06-01]. Available from https://www.ohchr.org/en/professionalinterest/pages/ccpr.aspx

[6] EUR-Lex: Directive 95/46/EC of the European Parliament and of the Council on the protection of individuals with regard to the processing of personal data and on the free movement of such data. [online]. 2018. [accessed 2018-05-25]. Available from WWW: https://eur-lex.europa.eu/legal-content/EN/TXT/?uri=CELEX\%3A31995L0046

[7] EUR-Lex: Regulation (EU) 2016/679 of the European Parliament and of the Council of 27 April 2016 on the protection of natural persons with regard to the processing of personal data and on the free movement of such data, and repealing Directive 95/46/EC (General Data Protection Regulation). [online]. 2018. [accessed 2018-05-25]. Available from WWW: https://eur-lex.europa.eu/eli/reg/2016/679/oj

[8] ÚŘAD PRO OCHRANU OSOBNÍCH ÚDAJU゚ (ÚOOÚ): Obecné nařizení. [online]. 2018. [accessed 2018-05-30]. Available from WWW: https://www.uoou.cz/1-obecnena-izeni/d-27266

[9] MICROSOFT: How to accelerate your GDPR journey. [online]. 2018. [accessed 201805-29]. Available from WWW: https://info.microsoft.com/CE-SCRTY-CNTNT-FY1808Aug-30-HowtoaccelerateyourGDPRjourney351101_004_01Registration-

ForminBody.html

[10] EU GDPR: Frequently Asked Questions about the GDPR. [online]. 2018. [accessed 2018-05-29]. Available from WWW: https://www.eugdpr.org/gdpr-faqs.html 
[11] CATANIA GROUP: Implementace GDPR do praxe úr̆adu. [online]. 2018. [accessed 2018-05-29]. Available from WWW:
content/uploads/2017/07/Implementace-GDPR-e-kniha.pdf

[12] SIEBER, R.: Připravenost firem v České republice na GDPR. ZČU v Plzni, Fakulta ekonomická, Plzeň, 2018. Diploma thesis.

[13] BÖHME, R. (ed.): The Economics of Information Security and Privacy. Springer, Münster, 2013. ISBN 978-3-642-39497-3. DOI: 1 10.1007/978-3-642-39498-0 


\section{PŘÍSTUP VYBRANÝCH PODNIKATELSKÝCH SUBJEKTU゚ K IMPLEMENTACI GDPR}

Ochrana osobních údajů je tématem, které začalo být řešeno v souvislosti s náboženskými konflikty. Do popředí se dostalo po druhé světové válce, která zviditelnila možné negativní důsledky zneužití osobních údajů. $\mathrm{V}$ současnosti je ochrana osobních údajů zmiňována v souvislosti s implementací nového Nařízení Evropského parlamentu a Rady EU členskými státy EU. Cílem předkládaného článku je vyhodnotit postoje dále specifikovaného výzkumného vzorku podnikatelských subjektů, které vykonávají svou činnost v České republice, ke změnám stanoveným prostřednictvím nové právní úpravy ochrany osobních údajů. Př́spěvek prezentuje zejména výstupy provedeného kvantitativního výzkumu založeného na sběru dat prostřednictvím dotazníkového šetření, identifikuje slabá místa procesu zavádění GDPR a navrhuje možná zlepšení vedoucí ke komfortnějšímu přechodu podnikatelských subjektů na současné legislativní podmínky v oblasti ochrany osobních údajů stanovené Evropským parlamentem a Radou EU.

\section{DER ANSATZ AUSGEWÄHLTER UNTERNEHMERISCHER SUBJEKTE ZUR IMPLEMENTIERUNG DER DATENSCHUTZVERORDNUNG}

Der Schutz der persönlichen Daten ist ein Thema, das bereits im Zusammenhang mit religiösen Konflikten gelöst wurde. In den Vordergrund rückte es nach dem zweiten Weltkrieg, welcher allfällige negative Konsequenzen des Missbrauchs persönlicher Daten sichtbar machte. In der Gegenwart findet der Schutz der persönlichen Daten Erwähnung im Zusammenhang mit der Implementierung der neuen Verordnung des Europäischen Parlamentes und des Europäischen Rates durch die Mitgliedsstaaten der EU. Das Ziel des vorliegenden Artikels besteht in der Auswertung der Haltung des weiter spezifizierten Forschungsmusters von Unternehmenssubjekten, welche ihre Tätigkeit in der Tschechischen Republik ausüben, zu den durch die neuen rechtlichen Regelungen zum Schutz der persönlichen Daten festgelegten Veränderungen. Der Beitrag präsentiert besonders die Ergebnisse der quantitativen Untersuchung, welche auf einer Fragebogenumfrage basiert, identifiziert die Schwachstellen des Prozesses der Einführung der Datenschutzverordnung und schlägt Verbesserungsmöglichkeiten vor, welche $\mathrm{zu}$ einem bequemeren Übergang der Unternehmenssubjekte zu den gegenwärtigen legislativen Bedingungen im Bereich des Schutzes persönlicher Daten führen, welcher vom Europäischen Parlament und vom Europäischen Rat festgelegt wurde.

\section{PODEJŚCIE WYBRANYCH PODMIOTÓW GOSPODARCZYCH DO WDROŻENIA RODO}

Ochrona danych osobowych to zagadnienie, którym zaczęto się zajmować w związku z konfliktami religijnymi. Pojawiło się po drugiej wojnie światowej, która uwidoczniła możliwe negatywne skutki nadużycia danych osobowych. Obecnie ochrona danych osobowych omawiana jest w związku z wdrożeniem nowego Rozporządzenia Parlamentu Europejskiego i Rady Unii Europejskiej przez państwa członkowskie Unii. Celem niniejszego artykułu jest ocena podejścia określonej próbki badawczej podmiotów gospodarczych, prowadzących działalność w Republice Czeskiej, do zmian określonych w nowej regulacji prawnej dotyczącej ochrony danych osobowych. W artykule zaprezentowano przede wszystkim wyniki przeprowadzonych badań ilościowych opartych na gromadzeniu danych w ramach badań ankietowych, zidentyfikowano słabe punkty procesu wdrażania RODO oraz zaproponowano możliwe udoskonalenia prowadzące do bardziej komfortowego dostosowania się podmiotów gospodarczych do obecnych warunków prawnych w zakresie ochrony danych osobowych określonych przez Parlament Europejski i Radę UE. 